\title{
PENENTUAN DAN APLIKASI FORMULA PEREKAT NABATI DARI EKSTRAK KULIT KAYU MAHONI PADA LAMINASI KAYU JABON (Anthocephalus cadamba)
}

\section{(Determination and Application of Bio-Adhesive Formula from Mahogany Bark Extract on Laminated Jabon Wood (Anthocephalus cadamba))}

\author{
Abdurachman, Adi Santoso, \& Rohmah Pari \\ Pusat Penelitian dan Pengembangan Hasil Hutan \\ Jl. Gunung Batu No. 5 Bogor 16610, Telp. (0251) 8633378, Faks. (0251) 8633413 \\ Email: profadisantoso@gmail.com
}

Diterima 24 Januari 2021, direvisi 28 Juni 2021, disetujui 2 Juli 2021

\begin{abstract}
The domestic need for phenolic-based wood adhesives is high, but the material is currently imported, then altenative adhesives are needed. This paper studies the characteristics of mahogany tannins and effective formulation of alternative adhesives made from mahogany bark extracts of mixture tapioca flour and industrial flour as extender applied to composite or glued products. The bark of mahogany was cut to the size of $2 \mathrm{~cm} \times 1 \mathrm{~cm} \times 0.1 \mathrm{~cm}$, extracted with hot water $\left(70-80^{\circ} \mathrm{C}\right)$ with a ratio of $1: 3(\mathrm{w} / \mathrm{w}$, material/water) for 3 hours with two repetitions. After extraction product was filtered, and the filtrate was copolymerized using resorcinol and formaldehyde under alkaline and room temperature conditions to produce resin tannin resorcinol formaldehyde (TRF). The blend of tapioca flour and industrial flour $(1: 1, w / w)$ as an extender was used in the TRF application to manufacture composite products. The results showed that this mahogany bark liquid extract could be copolymerized to form a resin which then applied as a wood adhesive in a cold pressing process. The optimum adhesive formula was a mixture of 0.25 mol of resorcinol and 1-mol formaldehyde, with a 15\% extender, and a catalyst (NaOH 40\%) of 4\% of the total weight of the adhesive formulation. The characteristics of mahogany tannin adhesives resemble those of the exterior type phenolic group.
\end{abstract}

Keywords: Extraction, formulation, mahogany bark waste, tapioca, industrial flour

\begin{abstract}
ABSTRAK
Kebutuhan perekat kayu berbasis fenolik dalam negeri tetap tinggi sedangkan bahan tersebut sampai saat ini merupakan bahan impor, sehingga diperlukan perekat alternatif. Penelitian ini bertujuan mempelajari karakteristik tanin mahoni dan formulasi efektif perekat alternatif berbahan baku ekstrak kulit pohon mahoni dengan ekstender tepung tapioka dan terigu industri untuk diaplikasikan pada produk komposit atau produk rekatan. Kulit kayu mahoni dipotong berukuran $2 \mathrm{~cm} \times 1 \mathrm{~cm}$ x 0,1 cm, diekstraksi dengan air panas $\left(70-80^{\circ} \mathrm{C}\right)$ pada perbandingan 1:3 (b/b, bahan/air) selama 3 jam dengan 2 kali pengulangan. Setelah produk ekstraksi disaring, filtratnya dikopolimerisasi menggunakan resorsinol dan formaldehida pada kondisi basa dan suhu kamar untuk menghasilkan resin tanin resorsinol formaldehida (TRF). Campuran tepung tapioka dan terigu industri $(1: 1 \mathrm{~b} / \mathrm{b})$ sebagai ekstender digunakan dalam aplikasi TRF pada pembuatan produk komposit. Hasil penelitian menunjukkan bahwa ekstrak cair kulit pohon mahoni ini dapat dikopolimerisasi membentuk resin yang dapat diaplikasikan sebagai perekat kayu dengan proses kempa dingin. Formula optimum perekat yang diperoleh adalah menggunakan campuran 0,25 mol resorsinol dan formaldehida $1 \mathrm{~mol}$, dengan ekstender 15\%, serta katalis $(\mathrm{NaOH} 40 \%)$ sebanyak $4 \%$ dari total bobot formula perekat. Karakteristik perekat tanin mahoni menyerupai perekat golongan fenolik tipe eksterior.
\end{abstract}

Kata kunci: Ekstraksi, formulasi, limbah kulit kayu mahoni, tapioka, terigu industri

\section{PENDAHULUAN}

Industri furnitur nasional mampu menembus pasar internasional melalui berbagai produk pengolahan kayu sebagaimana pencapaian nilai ekspor furnitur nasional tahun 2018 sebesar 1,69 miliar dolar AS atau naik 4\% dari pencapaian ekspor pada tahun 2017 dan nilai ekspor industri furnitur pada periode Januari tahun 2019 mencapai nilai 113,36 juta dolar AS atau naik 8,2\% dibandingkan dengan capaian pada Desember tahun 2018 (Kemenperin, 2019). Di tengah kondisi pandemi 
seperti saat ini pertumbuhan ekspor furnitur nasional masih ada meskipun target pertumbuhan ekspor tidak tercapai, akan tetapi permintaan produk furnitur untuk ekspor membaik pada kuartal akhir tahun 2020 (Sobur, 2021). Menteri Perindustrian optimis industri manufaktur seperti furnitur diharapkan menguat pada periode awal tahun 2021 seiring dengan kenaikan $1,27 \%$ nilai pembelian bahan baku sektor industri (Purchasing Managers Index, PMI) manufaktur Indonesia di tahun 2020 dan semakin terbukanya pasar global (Wisnubroto, 2020).

Di antara produk pengolahan kayu adalah produk rekatan. Kayu lamina sebagai salah satu produk kayu olahan tidak bisa lepas dari kebutuhan perekat yang sampai saat ini masih didominasi oleh perekat sintetis. Ketersediaan sumber bahan baku perekat sintetis di alam semakin berkurang dan umumnya produk yang menggunakan jenis perekat ini mengandung formaldehida, sehingga produk yang dihasilkan menimbulkan emisi formaldehida terhadap lingkungan, dan dalam konsentrasi tertentu berpotensi memberikan dampak buruk bagi kesehatan. Oleh karena itu, eksplorasi perekat alami sebagai alternatif pengganti perekat sintetis perlu dilakukan dalam upaya memenuhi kebutuhan perekat untuk produk rekatan.

Upaya pengembangan perekat organik terutama yang berbasis nabati sebagai alternatif pengganti perekat sintetis telah dilakukan. Ekstrak kulit kayu pohon akasia (Acacia decurrens Willd., A. mangium Willd.), bakau (Rhizophora spp.), dan tancang (Prunilva spp.) dapat dijadikan bahan pengganti fenol atau resorsinol karena banyak mengandung tanin yang terdiri atas senyawa fenolik (Santoso \& Abdurachman, 2016; Tahir, Halip, \& Lee, 2019). Guna mencegah ketergantungan bahan baku tanin terhadap kulit dari jenis pohon tertentu, beberapa penelitian mengkaji tanin dari kulit pohon jenis lain seperti kulit kayu mahoni (Swietenia mahagoni (L.) Jacq.). Komponen kimia yang terdapat pada kulit kayu mahoni ditengarai mengandung senyawa tanin (Falah, Suzuki, \& Katayama, 2008; Qodri, Masruri, \& Utomo, 2014; Rosdiana et al., 2017; Santoso \& Abdurachman, 2016; Triwahyuono \& Hidajati, 2020). Pengkajian aplikasi tanin dari ekstrak kulit kayu mahoni antara lain pada pembuatan lamina kayu sengon (Santoso \& Abdurachman, 2016), glulam kayu cepat tumbuh pinus-jabon-sengon (Lestari, Hadi, Hermawan, \& Santoso, 2015, 2019), lamina rotan (Pari, Abdurachman, \& Santoso, 2019). Perkembangan perekat berbasis tanin saat ini diharapkan dapat menggantikan penggunaan perekat sintetis pada kayu olahan. Penelitian ini bertujuan memperoleh formula yang optimal dari perekat berbasis tanin mahoni untuk perekatan kayu lamina jabon.

\section{BAHAN DAN METODE}

\section{A. Bahan dan Alat}

Bahan utama yang digunakan adalah kayu jabon (Anthocephalus cadamba Miq.) dan potongan atau cacahan limbah kulit kayu mahoni (Swietenia mahagoni (L.) Jacq.) yang diperoleh dari industri penggergajian kayu. Bahan penunjang berupa bahan kimia antara lain resorsinol sebagai aditif, larutan $\mathrm{NaOH} 50 \%$ sebagai katalis, formaldehida sebagai bridging agent, serta akuades sebagai pelarut. Peralatan pendukung bahan utama untuk pembuatan balok laminasi antara lain gergaji belah/potong, mesin serut, mesin ampelas, meteran, kuas. Peralatan pendukung bahan penunjang meliputi penangas air, beakerglass, gelas ukur, jam sukat (stopwatch), timbangan, viskometer Ostwald, oven, saringan 40 mesh, cawan petri, piknometer, kertas saring, $\mathrm{pH}$ universal, dan kertas label. Pengujian sifat mekanis kayu laminasi jabon menggunakan mesin uji Universal Testing Machine (UTM) berkapasitas 15 ton gaya.

\section{B. Metode}

1. Formulasi Perekat dari Ekstrak Kulit Kayu Mahoni

Proses formulasi dilakukan dengan menambahkan resorsinol untuk mengaktifkan senyawa fenolik pada tanin cair dari ekstrak kulit kayu mahoni. Tanin dari ekstrak kulit kayu mahoni (T) diformulasikan dengan resorsinol (R) dan formaldehida (F) dengan perbandingan mol $\mathrm{T}: \mathrm{R}: \mathrm{F}=1:(0 ; 0,10 ; 0,25 ; 0,50)$ : 1. Formulasi perekat yang terbaik dilanjutkan pencampuran dengan tepung tapioka dan terigu industri 1:1 (b/b) terdiri atas $(0 ; 2,5 ; 5 ; 10 ; 15 ; 20) \%$ dari bobot perekat cair sebagaimana diuraikan juga dalam Santoso (2003); Santoso dan Abdurachman (2016). Formulasi optimum perekat tanin dari ekstrak kulit kayu mahoni tersebut dianalisis sifat fisikokimianya dan ditelaah melalui pendekatan nilai keteguhan rekat produk perekatannya.

\section{Pengujian Sifat Fisiko-Kimia Perekat}

Perekat yang diperoleh dianalisis sifat fisikokimianya dengan mengacu pada SNI 06-0060 (SNI, 2000) antara lain uji visual, kekentalan, berat jenis, benda asing, kemasaman, kadar padatan, dan kadar formaldehida bebas. Hasil analisis tersebut dibandingkan dengan perekat phenol-formadehida (PF) pada SNI 4567-2000 (Phenol Formaldehida Cair Untuk Perekat Kayu Lapis (SNI, 2000) dan perekat phenol-resorsinol-formadehida (PRF) (Akzonobel, 2017). 


\section{Pembuatan dan Pengujian Kayu Komposit}

Produk perekatan yang dibuat di laboratorium berupa kayu laminasi. Kayu yang sudah dipersiapkan untuk penelitian dibelah dan dipotong menjadi papan bahan lamina berukuran $120 \mathrm{~cm}$ x $5,5 \mathrm{~cm} \times 1,2 \mathrm{~cm}$ untuk panjang, lebar dan tebal. Masing-masing papan diusahakan sama (homogen) dalam hal ukuran dan tanpa cacat. Setelah dipilih secara visual, kemudian papan ini dikeringkan pada suhu kamar hingga kadar airnya mencapai $14 \%$, selanjutnya papan tersebut dilaburi perekat dari ekstrak kulit kayu mahoni dan dibuat kayu komposit berupa balok lamina dengan lima garis rekat (enam lapis bilah).

Dimensi akhir balok lamina setelah diampelas berukuran $120 \mathrm{~cm} \times 5 \mathrm{~cm} \times 7 \mathrm{~cm}$ untuk panjang, lebar dan tebal (Gambar 1). Ukuran penampang $5 \mathrm{~cm} \times 7$ $\mathrm{cm}$ mengikuti ukuran balok struktural terkecil pada rangka atap (kaso). Formula perekat dilaburkan pada salah satu sisi kayu dengan bobot labur $170 \mathrm{~g} / \mathrm{m}^{2}$ permukaan. Setelah pelaburan merata, bilah-bilah papan direkatkan satu sama lain sejajar arah serat dan dikempa dingin dengan tekanan kempa $10 \mathrm{~kg} / \mathrm{cm}^{2}$ pada suhu kamar selama 8 jam dan 24 jam, serta didiamkan pada suhu ruang selama satu minggu sebelum dibuat potongan uji. Balok lamina (Gambar 1) yang telah dikondisikan selama 7 hari setelah perekatan, dibuat contoh uji terdiri atas kadar air, kerapatan, dan keteguhan rekat dengan mengacu pada standar uji JAS 234 (JAS, 2003).

\section{Analisis Data}

Data hasil pengamatan ditabulasi dan dirataratakan. Analisis statistik menggunakan rancangan acak lengkap dengan percobaan faktorial yang meliputi dua faktor, di mana faktor A, yaitu perbandingan mol $\mathrm{T}: \mathrm{R}: \mathrm{F}$ terdiri atas 4 taraf $(1:(0$; $0,10 ; 0,25 ; 0,50): 1)$, dan faktor $B$, yaitu pencampuran dengan tepung tapioka dan terigu industri (1:1) terdiri atas 6 taraf $(0 ; 2,5 ; 5 ; 10 ; 15 ; 20) \%$. Model matematikanya sebagai berikut:

$$
Y_{i j k}=\mu+\alpha_{i}+\beta_{j}+(\alpha \beta)_{i j}+\varepsilon_{i j k}
$$

$$
\begin{aligned}
\text { Keterangan } & \text { (Remarks): } \\
\mathrm{i}= & 1,2,3 \text {, dan } 4 ; \mathrm{j}=1,2,3,4,5 \text {, dan } 6 ; \mathrm{k}=1, \\
& 2,3 ; \\
\mathrm{Y}_{\mathrm{ijk}}= & \text { nilai rata-rata dari formulasi tanin yang ke- } \\
& \mathrm{k} \text { yang diberi resorsinol dan formaldehida } \\
& \text { ke-i dengan pencampuran tepung tapioka } \\
& \text { dan terigu industri ke-j; } \\
= & \text { rata-rata nilai formulasi sesungguhnya; } \\
= & \text { pengaruh perlakuan level perbandingan } \\
\mu & \text { T:R:F ke-i; } \\
\alpha_{\mathrm{i}}= & \text { pengaruh pencampuran tepung tapioka } \\
& \text { dan terigu industri ke-j; } \\
\beta_{\mathrm{j}}= & \text { pengaruh interaksi perlakuan ke-i dan ke-j; } \\
(\alpha \beta)_{\mathrm{ij}}= & \text { pengaruh galat perlakuan ke-i dan ke-j pada } \\
\varepsilon_{\mathrm{ijk}} \quad & \text { satuan percobaan ke-k. }
\end{aligned}
$$

Bila perlakuan berpengaruh nyata terhadap parameter yang diuji maka dilanjutkan dengan uji beda nyata dengan cara Turkey (Steel \& Torrie, 1990).

\section{HASIL DAN PEMBAHASAN}

Kopolimerisasi tanin dari ekstrak kulit kayu mahoni dengan resorsinol dan formaldehida, menggunakan aditif (ekstender) membentuk formula perekat kayu. Tulisan ini merupakan kelanjutan dari penelitian Santoso dan Abdurachman (2016) sebelumnya yang mendapatkan rendemen cair hasil ekstraksi tanin dari kulit mahoni dengan kadar $81 \%$, kadar padatan 1,5\%, dan tingkat reaktivitas tanin terhadap formaldehida (bilangan Stiasny) sebesar 92,12\%. Karakteristik perekat hasil formulasi dari ekstrak kulit kayu mahoni disajikan pada Tabel 1.

Spesifikasi jenis perekat tanin yang disintesis dari bahan baku alami seperti kulit kayu mahoni dibandingkan dengan PRF memiliki karakter yang berbeda. Kekentalan perekat tanin lebih tinggi dibandingkan dengan PRF, demikian pula $\mathrm{pH}$-nya. Kekentalan yang lebih tinggi akan berimbas terhadap kemampuan perekat berpenetrasi dan membentuk "jangkar" ke dalam sirekat, hingga proses curring berjalan sempurna. Nilai $\mathrm{pH}$ yang tinggi akan memperlambat proses pengerasan perekat, sehingga potlife-nya memadai manakala perekat dan sirekat saling berinteraksi selama proses pengempaan. Dengan demikian nilai kekentalan yang sesuai dengan nilai $\mathrm{pH}$ perekat akan menghasilkan ikatan antar molekul yang optimum.

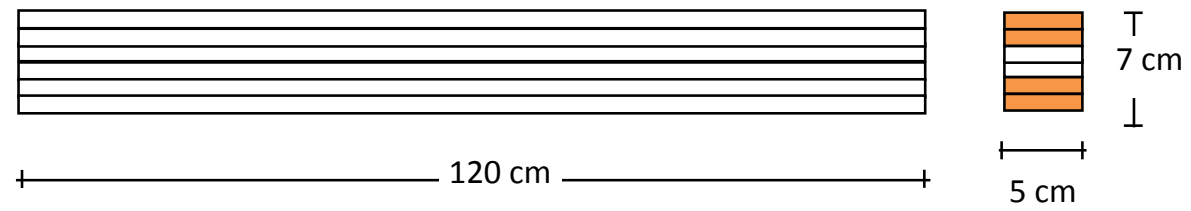


Tabel 1. Karakteristik fisiko-kimia perekat dari ekstrak kulit kayu mahoni pada komposisi formula optimum

Table 1. The fisico-chemistry of adhesive from mahogany bark extract on optimum formulation

\begin{tabular}{|c|c|c|c|}
\hline \multirow[b]{2}{*}{ No. } & \multirow{2}{*}{$\begin{array}{c}\text { Sifat } \\
\text { (Properties) }\end{array}$} & \multicolumn{2}{|c|}{ Jenis perekat (Types of adhesive) } \\
\hline & & $\begin{array}{c}\text { Perekat tanin mahoni } \\
\text { (Mabogany tannin adhesive) }\end{array}$ & $\begin{aligned} * & \text { Fenol resorsinol formaldeh } 101 \\
& \text { (Phenol resorcinol formaldebyde) }\end{aligned}$ \\
\hline \multirow[t]{4}{*}{1.} & Kenampakan: & & \\
\hline & - $\quad$ Bentuk (Phase) & Cair (Liquid) & Cairan kental (Tbick. liquid) \\
\hline & - Warna (Color) & $\begin{array}{l}\text { Merah-cokelat } \\
\text { (Red-brown) }\end{array}$ & $\begin{array}{c}\text { Merah-cokelat } \\
\text { (Red-brown })\end{array}$ \\
\hline & Bau $(S \operatorname{cent})$ & Fenol & Fenol \\
\hline 2. & Kekentalan (Viscosity, poise) & 11,35 & 3,40 \\
\hline 3. & Kemasaman $(\mathrm{pH})$ & 10,00 & 8,00 \\
\hline 4. & Bobot jenis (Specific gravity) & 1,07 & 1,15 \\
\hline
\end{tabular}

Keterangan (Remarks): * = Pembanding (Standard control)

Tolok ukur formula optimum perekat tanin mahoni maupun formula dengan campuran tepung tapioka dan terigu industri (1:1) sebagai ekstender masingmasing dilakukan dengan pendekatan nilai kadar padatan, formaldehida bebas dari formula perekat, dan keteguhan rekat produk perekatannya, yang hasilnya disajikan pada Tabel 2 .

Kadar air merupakan bobot air yang terkandung dalam kayu, dinyatakan sebagai persentase dari berat kering tanur pada kondisi kering (Tsoumis, 1991). Hasil pengujian produk perekatan dalam bentuk kayu lamina jabon menunjukkan bahwa kadar air keseluruhan produk berada di kisaran 11,12-14,70\% (Tabel 2), sementara hasil penelitian terdahulu berkisar 10,89-14,18 \% (Santoso \& Abdurachman, 2016), $12,75 \pm 0,04 \%$ (Lestari et al., 2015) dan $10,87 \pm 0,02 \%$ (Lestari et al., 2019). Kadar air tersebut memenuhi Japanese Agricultural Standards (JAS) JAS, 2003) karena nilainya $<15 \%$. Menurut analisis keragaman kerapatan, produk perekatan ini dipengaruhi oleh formula perekat dan kadar ekstender yang digunakan. Di pihak lain, kerapatan produk perekatan berkisar $0,35-0,42 \mathrm{~g} / \mathrm{cm}^{3}$ yang setara dengan hasil penelitian sebelumnya pada produk sejenis (Lestari et al., 2015, 2019; Santoso \& Abdurachman, 2016).

Kadar padatan (solid content) perekat yang dibuat dari ekstrak tanin cair dengan nilai terendah adalah $7,76 \%$ dengan formulasi $a_{1} b_{1}$, sedangkan nilai tertinggi adalah $23,76 \%$ dengan formulasi $a_{4} b_{6}$, sementara hasil penelitian sebelumnya dari formula perekat tanin mahoni yang menggunakan ekstender tepung tapioka saja berkisar 6-37,96\% (Santoso \& Abdurachman, 2016). Ada kecenderungan bahwa besarnya nilai kadar padatan dipengaruhi oleh kadar resorsinol dan kadar ekstendernya. Terlihat bahwa semakin besar mol resorsinol dan kadar ekstender maka semakin besar pula nilai kadar padatannya (Tabel 2). Pada prakteknya kadar padatan formula perekat tanin mahoni yang terlalu tinggi $(37,58 \%)$ memiliki potlife yang sangat singkat, sehingga menyulitkan aplikasinya karena terlalu cepat mengeras, dengan demikian kadar padatan optimum adalah $23,59 \%$ dengan formula $a_{3} b_{5}$.

Formulasi optimum perekat pada berbagai karakteristik terutama ditentukan berdasarkan nilai keteguhan rekat, yang masing-masing diuji dalam kondisi kering dan basah. Keteguhan rekat tertinggi yang diuji dalam kondisi kering dicapai oleh kayu laminasi yang menggunakan perekat tanin ekstrak kulit kayu mahoni dengan formulasi kadar resorsinol 0,25 mol dan 15\% ekstender $\left(a_{3} b_{5}\right)$ (Tabel 2), memenuhi persyaratan standar JAS (JAS, 2003) karena nilainya berada dalam kisaran $54-96 \mathrm{~kg} / \mathrm{cm}^{2}$. Hasil penelitian terdahulu terhadap produk kayu laminasi dengan jenis perekat yang sama namun menggunakan ekstender tepung tapioka saja menghasilkan keteguhan rekat kayu lamina sengon rata-rata 27,44-102,13 $\mathrm{kg} / \mathrm{cm}^{2}$ (Santoso \& Abdurachman, 2016). Di lain pihak, keteguhan rekat produk serupa yang menggunakan perekat isosianat (impor) rata-rata $55,10 \mathrm{~kg} / \mathrm{cm}^{2}$ dan $47,2 \mathrm{~kg} / \mathrm{cm}^{2}$ (Lestari et al., 2015), dan produk sejenis dari kayu sengon dengan perekat dari ekstrak kayu merbau mendapatkan nilai keteguhan rekat $65,3 \mathrm{~kg} / \mathrm{cm}^{2}$, sedangkan yang menggunakan perekat impor (PRF) memiliki keteguhan rekat sebesar $54,97 \mathrm{~kg} / \mathrm{cm}^{2}$ (Santoso et al., 2014). 
Tabel 2. Optimalisasi formula perekat tanin dari ektrak kulit kayu mahoni berdasarkan nilai rata-rata solid content, formaldehida bebas formula perekat, dan keteguhan rekat produk kayu lamina jabon

Table 2. Optimization of tannin adhesive formulation from mahogany bark extract based on mean value of solid content, adhesive-free formaldehyde, and products of jabon lamination timber

\begin{tabular}{|c|c|c|c|c|c|c|c|c|}
\hline \multirow{2}{*}{\multicolumn{2}{|c|}{$\begin{array}{c}\text { Sifat } \\
\text { (Properties) }\end{array}$}} & \multirow{2}{*}{$\begin{array}{c}\text { Resorsinol } \\
\text { (Resorcinol, } \\
\text { A, mol) }\end{array}$} & \multicolumn{6}{|c|}{$\begin{array}{c}\text { Kadar ekstender } \\
\text { (Content of extender, B, \%) }\end{array}$} \\
\hline & & & 0 (b1) & 2,5 (b2) & 5,0 (b3) & $10(\mathrm{~b} 4)$ & 15 (b5) & 20 (b6) \\
\hline \multirow{4}{*}{\multicolumn{2}{|c|}{$\begin{array}{c}\text { Kadar air } \\
\text { (Moisture content, \%) }\end{array}$}} & 0,00 (a1) & $14,29 \mathrm{~b}$ & $14,18^{\mathrm{b}}$ & $14,26^{\mathrm{b}}$ & $14,32^{\mathrm{b}}$ & $14,08^{\mathrm{b}}$ & $14,07^{b}$ \\
\hline & & 0,10 (a2) & $13,32^{c}$ & $11,37^{\text {efgh }}$ & $11,35^{\mathrm{fgh}}$ & $12,34 \mathrm{~d}$ & $13,42^{c}$ & $11,63^{e}$ \\
\hline & & 0,25 (a3) & $11,15^{\mathrm{h}}$ & $11,42^{\mathrm{efg} g}$ & $12,42^{\mathrm{d}}$ & $11,12^{\mathrm{h}}$ & $11,20 \mathrm{gh}$ & $11,54^{\mathrm{ef}}$ \\
\hline & & $0,50(\mathrm{a} 4)$ & $14,17^{b}$ & $13,49^{c}$ & $12,58^{\mathrm{d}}$ & $14,59^{\mathrm{a}}$ & $14,70^{\mathrm{a}}$ & $14,61^{\mathrm{a}}$ \\
\hline \multirow{4}{*}{\multicolumn{2}{|c|}{$\begin{array}{c}\text { Kerapatan } \\
\left(\text { Density, g/ } \mathrm{cm}^{3}\right)\end{array}$}} & 0,00 (a1) & $0,41^{\mathrm{ab}}$ & $0,41^{\mathrm{ab}}$ & $0,42^{a}$ & $0,40^{\mathrm{abc}}$ & $0,41 \mathrm{ab}$ & $0,41^{\mathrm{ab}}$ \\
\hline & & 0,10 (a2) & $0,41^{\mathrm{ab}}$ & $0,37^{e}$ & $0,37^{\mathrm{e}}$ & $0,37^{e}$ & $0,37^{\mathrm{e}}$ & $0,37 \mathrm{e}$ \\
\hline & & 0,25 (a3) & $0,35^{\mathrm{f}}$ & $0,38^{\mathrm{de}}$ & $0,42^{\mathrm{a}}$ & $0,37 \mathrm{de}$ & $0,37^{\mathrm{e}}$ & $0,37^{\mathrm{e}}$ \\
\hline & & $0,50(\mathrm{a} 4)$ & $0,37 \mathrm{e}$ & $0,39 \mathrm{~cd}$ & $0,39 \mathrm{~cd}$ & $0,42^{\mathrm{a}}$ & $0,42^{\mathrm{a}}$ & $0,42^{\mathrm{a}}$ \\
\hline \multirow{4}{*}{\multicolumn{2}{|c|}{$\begin{array}{l}\text { Kadar padatan } \\
\text { (Solid content, \%) }\end{array}$}} & 0,00 (a1) & $7,76^{t}$ & $8,79^{r}$ & $9,72^{q}$ & $11,71^{\mathrm{n}}$ & $16,74^{\mathrm{i}}$ & $21,78^{\mathrm{d}}$ \\
\hline & & 0,10 (a2) & $8,11^{\mathrm{s}}$ & $9,78 q$ & $10,15 \mathrm{p}$ & $11,78^{n}$ & $17,71 \mathrm{~g}$ & $19,75^{\mathrm{e}}$ \\
\hline & & 0,25 (a3) & $10,70^{\circ}$ & $12,61^{\mathrm{m}}$ & 14,741 & $15,27 \mathrm{k}$ & $23,59 \mathrm{~b}$ & $37,58^{a}$ \\
\hline & & $0,50(\mathrm{a} 4)$ & $15,41^{\mathrm{k}}$ & $16,40 j$ & $17,35^{\mathrm{h}}$ & $18,33^{\mathrm{f}}$ & $22,26^{c}$ & $23,76^{\mathrm{b}}$ \\
\hline \multirow{8}{*}{$\begin{array}{l}\text { Keteguhan } \\
\text { rekat } \\
(\text { Bonding } \\
\text { strength, } \\
\left.\mathrm{kg} / \mathrm{cm}^{2}\right)\end{array}$} & \multirow{4}{*}{$\begin{array}{l}\text { Uji Kering } \\
\text { (Dry test) }\end{array}$} & 0,00 (a1) & $29,66^{\mathrm{w}}$ & $33,41^{t}$ & $37,43^{\circ}$ & $43,59^{k}$ & $63,75^{b}$ & $46,59^{\mathrm{h}}$ \\
\hline & & 0,10 (a2) & $34,43^{\mathrm{s}}$ & $36,70 \mathrm{p}$ & $42,71^{1}$ & $47,49 \mathrm{~g}$ & $63,69^{b}$ & $50,59^{d}$ \\
\hline & & 0,25 (a3) & $35,70 q$ & $39,72^{\mathrm{m}}$ & $46,60^{\mathrm{h}}$ & $50,36^{\mathrm{e}}$ & $82,77^{a}$ & $56,77 \mathrm{c}$ \\
\hline & & $0,50(\mathrm{a} 4)$ & $31,24^{v}$ & $31,52^{\mathrm{u}}$ & $35,41^{\mathrm{r}}$ & $39,23^{\mathrm{n}}$ & $48,37^{\mathrm{f}}$ & $45,61^{\mathrm{h}}$ \\
\hline & \multirow{4}{*}{$\begin{array}{l}\text { Uji Basah } \\
\text { (Wet test) }\end{array}$} & 0,00 (a1) & $7,29 \mathrm{r}$ & $9,30 \mathrm{p}$ & $17,15^{\mathrm{i}}$ & $18,59 \mathrm{~g}$ & $10,87^{\circ}$ & $8,78 q$ \\
\hline & & 0,10 (a2) & $14,49^{1}$ & $17,49 \mathrm{~h}$ & $19,55^{\mathrm{f}}$ & $22,70^{c}$ & $18,62^{g}$ & $16,74 j$ \\
\hline & & 0,25 (a3) & $20,34^{e}$ & $29,61^{a}$ & $23,58^{\mathrm{b}}$ & $21,54^{d}$ & $17,14^{\mathrm{i}}$ & $13,72^{\mathrm{m}}$ \\
\hline & & $0,50(\mathrm{a} 4)$ & $17,53^{\mathrm{h}}$ & $23,60^{\mathrm{b}}$ & $19,40^{\mathrm{f}}$ & $15,37 \mathrm{k}$ & $13,36^{\mathrm{n}}$ & $9,33 \mathrm{p}$ \\
\hline \multirow{4}{*}{\multicolumn{2}{|c|}{$\begin{array}{l}\text { Formaldehida bebas } \\
\text { (Free formaldebyde, mg/L) }\end{array}$}} & 0,00 (a1) & $0,0041^{\text {def }}$ & $0,0048^{\mathrm{bcd}}$ & $0,0056^{\mathrm{ab}}$ & $0,0059^{a}$ & $0,0060^{a}$ & $0,0061^{a}$ \\
\hline & & 0,10 (a2) & $0,0036^{\text {efgh }}$ & $0,0042^{\mathrm{def}}$ & $0,0045^{\mathrm{cd}}$ & $0,0056^{\mathrm{ab}}$ & 0,0054abc & $0,0046^{\mathrm{cd}}$ \\
\hline & & 0,25 (a3) & $0,0032^{\mathrm{gh}}$ & $0,0041 \mathrm{~d}^{\mathrm{ef}}$ & $0,0043^{\text {def }}$ & $0,0048^{\mathrm{bcd}}$ & 0,0044 def & 0,0041 def \\
\hline & & $0,50(\mathrm{a} 4)$ & $0,0030 \mathrm{gh}$ & 0,0039 defg & 0,0039 defg & 0,0044 def & $0,0042^{\text {def }}$ & 0,0040 defg \\
\hline
\end{tabular}

Keterangan (Remarks): Huruf yang sama di belakang angka menunjukkan tidak berbeda nyata (Values followed by the same latter is not significant)

Aplikasi resin dari ekstrak kayu mahoni pada kayu lamina jabon yang diuji dalam keadaan basah untuk produk tipe eksterior (outdoor) menghasilkan keteguhan rekat 7,29-29,61 $\mathrm{kg} / \mathrm{cm}^{2}$, dengan keteguhan rekat tertinggi diperoleh pada produk dengan formulasi perekat $a_{3} b_{2}$ (Tabel 2). Hasil penelitian terdahulu terhadap produk kayu laminasi dengan jenis perekat yang sama namun menggunakan ekstender tepung tapioka saja menghasilkan keteguhan rekat kayu lamina sengon yang diuji dalam kondisi basah rata-rata $6,72-23,78 \mathrm{~kg} / \mathrm{cm}^{2}$ (Santoso \& Abdurachman, 2016), sementara keteguhan rekat hasil penelitian serupa pada jenis kayu yang sama dengan menggunakan perekat dari ekstrak kayu merbau rata-rata $32,32 \mathrm{~kg} / \mathrm{cm}^{2}$, dan yang menggunakan perekat impor (PRF) $24,4 \mathrm{~kg} / \mathrm{cm}^{2}$ (Santoso et al., 2014).

Kadar formaldehida bebas menggambarkan adanya kelebihan formaldehida yang tidak bereaksi dalam pembentukan suatu polimer (SNI, 2000). Penetapan ini dilakukan dengan tujuan untuk mengetahui jumlah kelebihan formaldehida yang tidak bereaksi dalam pembentukan resin dari ekstrak kulit kayu mahoni, dan tingkat emisi yang kemungkinan terjadi sebagai akibat formaldehida 


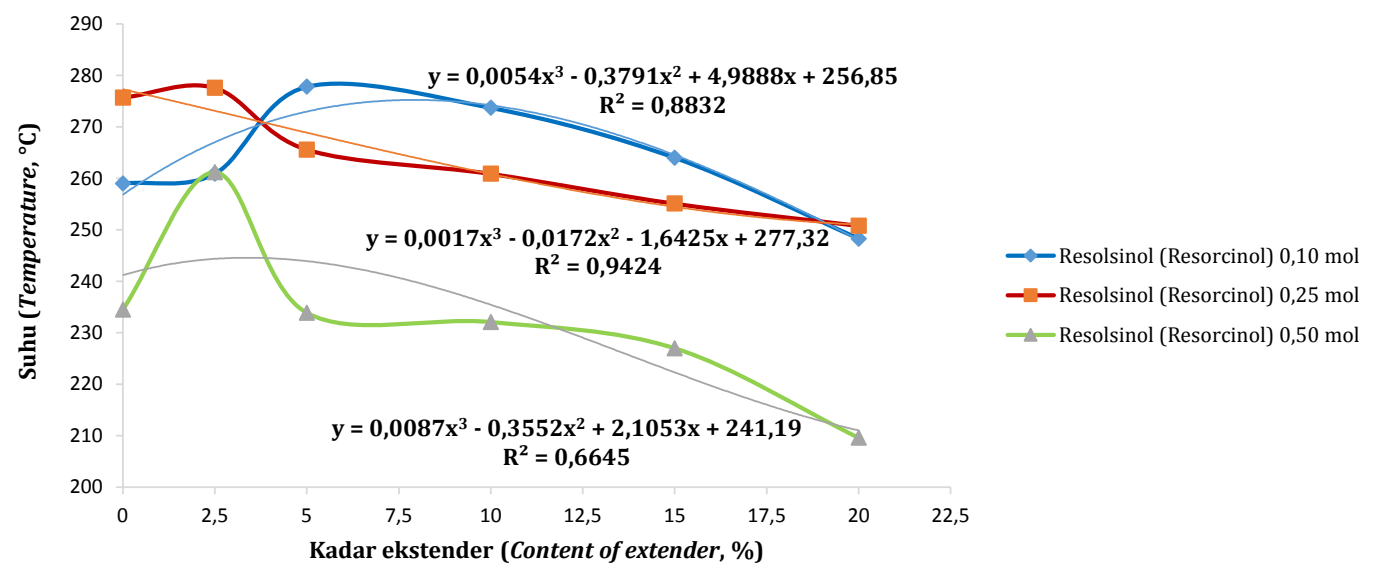

Gambar 2. Sifat thermal perekat tanin dari ekstrak kulit kayu mahoni Figure 2. Thermal properties of tannin adhesive from mahogany bark extract

yang dilepaskan. Nilai rata-rata formaldehida bebas paling rendah diperoleh $0,003 \mathrm{mg} / \mathrm{L}$ pada formulasi $\mathrm{a}_{4} \mathrm{~b}_{1}$ dan tertinggi $0,0061 \mathrm{mg} / \mathrm{L}$ pada formulasi $\mathrm{a}_{1} \mathrm{~b}_{6}$ (Tabel 2).

Meningkatnya penggunaan resorsinol dalam formulasi menyebabkan kadar formaldehida bebas resin semakin berkurang, mengindikasikan bahwa resorsinol berperan dalam mengikat kelebihan formaldehida bebas (Tabel 2), sementara penggunaan kadar ekstender yang semakin meningkat cenderung mempertinggi kadar formaldehida bebas resin, kecuali pada formula a3 dan a 4 yang meningkat sampai pada batas tertentu untuk selanjutnya semakin berkurang, namun demikian interaksi dari kedua hal tersebut untuk seluruh formula menghasilkan nilai formaldehida bebas yang jauh di bawah ambang batas maksimal, karena kurang dari 3\% seperti yang disyaratkan bagi perekat yang mengandung formaldehida (SNI, 1998).

Pengujian stabilitas perekat terhadap suhu tinggi untuk aplikasi tipe eksterior dilakukan dengan metode Differensial Scanning Calorimetri (DSC), yang hasilnya disajikan dalam Gambar 2. Secara umum, seluruh formula perekat tanin mahoni ini memiliki ketahanan terhadap suhu tinggi $\left(>200^{\circ} \mathrm{C}\right)$. Artinya, perekat ini bila diaplikasikan pada kayu akan tetap stabil pada perlakuan uji perendaman dalam air mendidih karena hasil uji DSC menunjukkan perubahan fase (titik gelas) perekat terjadi pada suhu antara $209,6-277,8^{\circ} \mathrm{C}$.

Gambar 2 di atas juga menunjukkan pemakaian ekstender berakibat menurunkan titik gelas perekat, namun penggunaan ekstender sampai pada kadar maksimum dalam penelitian ini, nilainya masih di atas suhu titik didih air. Dengan demikian formula manapun yang digunakan dapat diaplikasikan untuk tipe eksterior. Sebagai aplikasi dari kegiatan penelitian ini adalah menerapkan perekat dengan formulasi optimum berdasarkan uji keteguhan rekat kering, yaitu formulasi dengan $a_{3} b_{5}$ atau 0,25 mol resorsinol ditambah 15\% ekstender pada produk kayu laminasi.

\section{KESIMPULAN DAN SARAN}

\section{A. Kesimpulan}

Ekstrak cair dari kulit pohon mahoni ini dapat dikopolimerisasi membentuk resin yang dapat diaplikasikan sebagai perekat kayu dengan proses kempa dingin. Karakteristik perekat ini berbeda dengan bahan bakunya baik secara kualitatif maupun kuantitatif. Formula optimum perekat dari ekstrak kulit kayu mahoni adalah yang menggunakan campuran 0,25 mol resorsinol dengan ekstender berupa campuran tepung tapioka dan terigu industri (1:1) sebanyak $15 \%$, serta formaldehida 1 mol dengan katalis $(\mathrm{NaOH} 40 \%)$ sebanyak $4 \%$ dari total bobot perekat. Karakteristik perekat tanin mahoni menyerupai perekat golongan fenolik tipe eksterior dengan formaldehida bebas yang memenuhi standar SNI untuk perekat berbasis fenolik.

\section{B. Saran}

Perekat dengan formula optimum disarankan agar diujicobakan dalam skala industri untuk mendapatkan kepastian perihal potensi penggunaannya sebagai perekat kayu komposit.

\section{UCAPAN TERIMA KASIH}

Ucapan terima kasih disampaikan kepada Pusat Penelitian dan Pengembangan Hasil Hutan yang telah mendanai penelitian melalui DIPA. Ucapan terima kasih disampaikan kepada Dr. Ir. Han Roliadi, M.Sc. yang telah membantu pendataan dalam penelitian ini. Terimakasih juga disampaikan kepada para teknisi di laboratorium kelompok peneliti Pemanfaatan Hasil Hutan yang telah membantu pelaksanaan penelitian. 


\section{KONTRIBUSI PENULIS}

Ide, desain dan rancangan percobaan dilakukan oleh AR dan AS. Pengambilan data dilakukan oleh AR dan AS. Analisis data serta penulisan manuskrip dilakukan oleh AR, AS, dan RP. Perbaikan dan finalisasi manuskrip dilakukan oleh AR, AS, dan RP.

\section{DAFTAR PUSTAKA}

Akzonobel. (2001). Synteko phenol-resorcinol adhesive 1711 with hardeners 2620, 2622, 2623. Casco Adhesive, Asia.

Falah, S., Suzuki, T., \& Katayama, T. (2008). Chemical constituents from Swietenia macrophylla bark and their antioxidant activity. Pakistan Journal of Biological Sciences, 11(16), 2007-2012. doi: 10.3923/pjbs.2008.2007.2012.

Japanese Agricultural Standard (JAS). (2003). Glued laminated timber (JAS 234-2003). Japanese Plywood Inspection Corporation (JPIC).

Kemenperin, (Kementerian Perindustrian RI). (2019, March 17). Agresif dobrak pasar ekspor, industri furnitur dan kerajinan raih surplus. Siaran Pers. doi://www.kemenperin.go.id/ artikel/20443/Agresif-Dobrak-Pasar-Ekspor,Industri-Furnitur-dan-Kerajinan-Raih-Surplus pada tanggal 16 Maret 2021

Lestari, A. S. R. D., Hadi, Y. S., Hermawan, D., \& Santoso, A. (2015). Glulam properties of fastgrowing species using mahogany tannin adhesive. BioResources, 10(4), 7419-7433. doi: 10.15376/biores.10.4.7419-7433.

Lestari, A. S. R. D., Hadi, Y. S., Hermawan, D., Santoso, A., \& Pizzi, A. (2019). Physical and mechanical properties of glued-laminated lumber from fast-growing tree species using mahogany tannin adhesive. Wood and Fiber Science, 51(2), 1-12. doi: 10.22382/ wfs-2019xxx.

Pari, R., Abdurachman, \& Santoso, A. (2019). Keteguhan rekat dan emisi formaldehida papan lamina rotan menggunakan perekat tanin formaldehida. Jurnal Penelitian Hasil Hutan, 37(1), 33-41. doi: 10.20886/JPHH.2019.37 .1.33-41.

Qodri, U. L., Masruri, \& Utomo, E. P. (2014). Skrining fitokimia metabolit sekunder ekstrak metanol dari kulit batang mahoni (Swietenia mabagony Jacq.). Jurnal Ilmu Kimia Universitas Brawijaya, 2(2), 480-484. doi://kimia.student journal.ub.ac.id/index.php/jikub/article/view/ $529 / 210$.

Rosdiana, N. A., Dumarçay, S., Gérardin, C., Chapuis, H., Santiago-Medina, F. J., Sari, R. K., Syafii, W., Gelhaye, E., Raharivelomanana, P., Mohammed, R., \& Gérardin, P. (2017).
Characterization of bark extractives of different industrial Indonesian wood species for potential valorization. Industrial Crops and Products, 108, 121-127. doi: 10.1016/j.indcrop. 2017.06.034.

Santoso, A. (2003). Sintesis dan karakterisasi resin lignin resorsinol formaldehida untuk perekat kayu lamina. Desertasi Doktor. Institut Pertanian Bogor, Bogor.

Santoso, A., \& Abdurachman. (2016). Karakteristik ekstrak kulit kayu mahoni sebagai bahan perekat kayu. Jurnal Penelitian Hasil Hutan, 34(4), 269284. doi: 10.20886/jphh.2016.34.4. 269-284.

Santoso, A., Hadi, Y. S., \& Malik, J. (2014). Composite flooring quality of combined wood species using adhesive from merbau wood extract. Forest Products Journal, 64(5-6), 179-186. doi: 10.13073/FPJ-D-13-00051.

Standar Nasional Indonesia (SNI). (2000). Fenol formaldehida cair untuk perekat kayu lapis (SNI 4567-2000). Badan Standardisasi Nasional, Jakarta.

Sobur, A. (2021, January 30). Target ekspor tak tercapai, industri mebel dan kerajinan dapat secercah pintu rezeki di akhir tahun 2020. Himpunan Industri Mebel Dan Kerajinan Indonesia (HIMKI). Diakses dari https://www. himki-indonesia.com/post/ view/253-id-target -ekspor-tak-tercapai-industri-mebel- dan- keraji nan-dapat-secercah-pintu-rezeki-di-akhir-tahun -2 pada tanggal 30 Maret 2021.

Steel, R. G. D., \& Torrie, J. H. (1990). Principles and procedure of statistic. New York: Mc. Graw Hill Book Company.

Tahir, P. M., Halip, J. A., \& Lee, S. H. (2019). Tanninbased bioresin as adhesives. Dalam Lignocellulose for Future Bioeconomy (pp. 109-133). Elsevier. doi: 10.1016/B978-0-12-816354-2.00007-4.

Triwahyuono, D. A., \& Hidajati, N. (2020). Uji fitokimia ekstrak etanol kulit batang mahoni (Swietenia mabagoni Jacq.). UNESA Journal of Chemistry, 9(1), 54-57. doi://jurnalmahasiswa. unesa.ac.id/ index. php/ unesa- journal- of- che mistry/article/view/32784.

Tsoumis, G. T. (1991). Science and technology of wood : structure, properties, utilization. Dalam Science and technology of wood. Structure, properties, utilization. Van Nostrand Reinhold.

Wisnubroto, K. (2020, November 17). Industri mebel bising kembali. Portal Informasi Indonesia. doi://indonesia.go.id/narasi/indonesia-dalamangka/ekonomi/industri-mebel-bising-kembali. 